\title{
MINERAL CONTENT ANALYSIS OF UNIFLORAL HONEYS FROM THE HUNGARIAN GREAT PLAIN*
}

\author{
Attila Ördög ${ }^{1}$, Irma Tari ${ }^{1}$, Zoltán Bátori ${ }^{2}$, Péter Poór ${ }^{1}$ \\ ${ }^{1}$ Department of Plant Biology \\ ${ }^{2}$ Department of Ecology \\ University of Szeged, Hungary
}

\begin{abstract}
Honey is a key product of the traditional agriculture in Hungary and an important export commodity of the Hungarian commerce. The content of metals in honeys is essential for food quality and safety, in addition to which it provides elemental fingerprints about the region where the honey was collected. The aim of this study was to determine and compare the element content of black locust, oilseed rape and sunflower honey samples collected from the southern part of the Hungarian Great Plain. The major ( $\mathrm{K}$ and $\mathrm{Mg}$ ), trace (Fe, $\mathrm{Zn}, \mathrm{Cu}, \mathrm{Mn}, \mathrm{B}, \mathrm{Al}, \mathrm{Co}, \mathrm{Ni}$, Se and $\mathrm{Mo}$ ) and toxic elements $(\mathrm{As}, \mathrm{Pb}$ and $\mathrm{Cd}$ ) of the samples were determined by Inductively Coupled Plasma-Mass Spectrometry (ICP-MS). Principal Component Analysis (PCA) was performed to compare the mineral content of the different honey types. Our analyses revealed that $\mathrm{K}$ was the most abundant element in the investigated honey samples. Among the trace elements, B, Fe, $\mathrm{Zn}$ and $\mathrm{Cu}$ were found in the highest concentrations. Sunflower honey contained the highest concentrations of $\mathrm{K}, \mathrm{Mg}$ and $\mathrm{Mn}$, while oilseed rape honey showed the highest $\mathrm{B}$ content. The mineral content of honeys decreased in order of sunflower, oilsed rape and black locust. There were no differences among the honey types in the toxic element content ( $\mathrm{As}, \mathrm{Pb}$ and $\mathrm{Cd}$ ), which was under the detection limit in many honey samples. According to the multivariate method, the $\mathrm{Mg}, \mathrm{B}, \mathrm{Al}, \mathrm{K}$ and $\mathrm{Zn}$ contents are considered to be the most important indicator for distinguishing the investigated honey samples and types. The results obtained from the mineral content analyses showed that differences in major, trace and toxic elements between Hungarian unifloral honeys as well as a detailed comparison of honeys with different geographic origins can be used for quality assessment.
\end{abstract}

Keywords: honey characterization, Hungarian honey, ICP-MS, mineral content, unifloral honey.

Péter Poór PhD, Department of Plant Biology, University of Szeged, Közép fasor 52, H-6726 Szeged, Hungary, phone/fax.: +36 62 544307, e-mail: poorpeti@bio.u-szeged.hu

* This work was supported by the Social Renewal Operational Programme (grant no. TÁMOP-4.1.1.C- 12/1/KONV-2012-0014). 


\section{INTRODUCTION}

Honey quality has significant economic importance, since it affects food processing, production and consumer expectations. Owing to the geographic and climatic conditions, honey production and beekeeping have been important agricultural activities for hundreds of years in Hungary and especially in the Hungarian Great Plain (SzÚCS 2010). According to the data given by the National Hungarian Apiculture Association (Országos Magyar Méhészeti Egyesület, OMME), there were 18,782 beekeepers in Hungary in 2011, and $1,065,860$ honey bee colonies produced about 20,000 tons of honey per year (TóтH 2011). There are some regions in Hungary which provide a unique opportunity for food and honey production activities. One of the most important areas, from both a commercial and economic point of view, is the Hungarian Great Plain. This area is characterized by a continental climate and special soil conditions. Many types of unifloral (black locust, rape and sunflower) and multifloral honeys of this region are produced by about 28,000 honey bee colonies (То́тн 2011).

Chemical markers based on the analysis of the compositional data of honey volatile compounds, phenolic acids, flavonoids, carbohydrates, amino acids and mineral contents, are optimal to investigate the authentication and characterization of botanical and geographic origins of unifloral honeys (KaŠKONIENĖ, VenskUtonis 2010). However, one of the most important indicators of honey quality is the mineral content, which strongly depends on the geographic origin of honeys and can be used for the classification of honey samples (Terrab et al. 2004, Hernandez et al. 2005, Bogdanov et al. 2007, Tuzen et al. 2007, Pisani et al. 2008, KašKonienė, Venskutonis 2010, NowaK et al. 2011, De Alda-Garcilope et al. 2012, Chen et al. 2014). The macro- (K, Ca, $\mathrm{Mg}$ and $\mathrm{Na}$ ), trace $(\mathrm{Fe}, \mathrm{Cu}, \mathrm{Mn}, \mathrm{Zn}, \mathrm{B}, \mathrm{Ni}$ and $\mathrm{Co}$ ) and toxic elements (As, $\mathrm{Cd}, \mathrm{Pb}$ ) are taken up by the plant's root system, transported to flowers via stems and finally secreted into nectar, which is the source of honey. Thus, the mineral content of honey mostly depends on the soil composition and also on the type of plant species (PrZYbyŁowski, Wilczý́ska 2001, STANkovska et al. 2008, PoHL 2009). Some of the heavy metals (e.g. As, Pb and Cd) can accumulate in honey as a result of environmental contamination (ConTI, Botre 2001, Pohl 2009, CitaK et al. 2012). As well as being an important indicator of honey quality, the metal content provides elemental fingerprints about the region where the honey was collected. Trace element analysis by Inductively Coupled Plasma-Mass Spectrometry (ICP-MS) together with multivariate analysis are useful tools for identification of honey authenticity using the mineral content profile; becides, they reveal the relationship between the distribution of elements and unifloral honey types (CHUDZINSKA, BARALKIEWICZ 2010).

The mineral content of the Hungarian honeys has been studied for just some species (CZIPA et al. 2008, ZAJÁcZ et al. 2008) and no data are available 
on the metal content of unifloral honeys originated from the Hungarian Great Plain. Our aim was to study the mineral content of unifloral honeys from the southern part of the Hungarian Great Plain and to compare the macro-, trace and toxic element content of honey samples from this region using ICP-MS, which can help to classify the honeys according to their botanical and geographic origin.

\section{MATERIAL AND METHODS}

\section{Samples}

Twenty-seven unifloral honey (black locust, rape and sunflower) samples were collected in 2013 and 2014 from different locations of the Hungarian Great Plain (Figure 1). The honey samples were taken directly from beek-

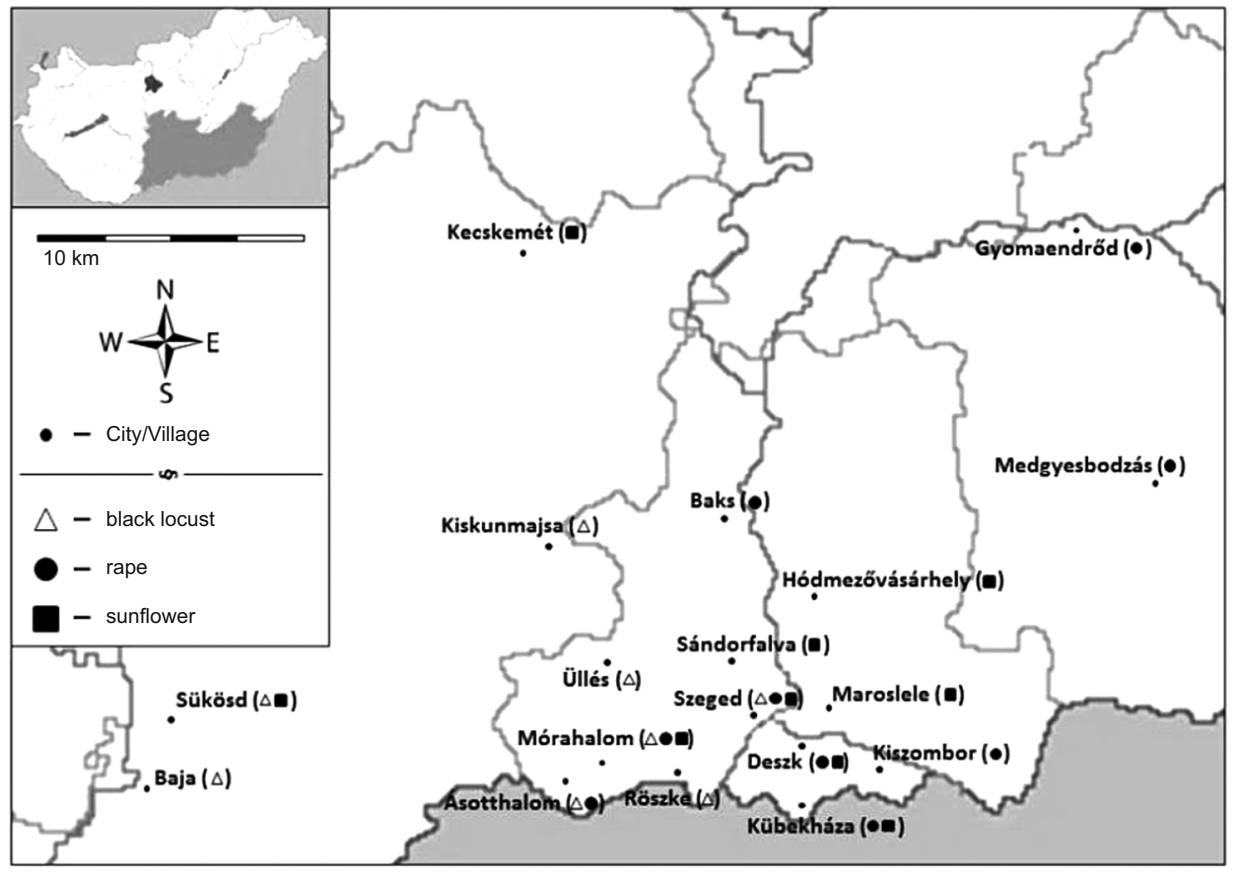

Fig. 1. Locations of the sampling points in Hungary

eepers. All samples were unpasteurized and were taken no more than three months after extraction. Samples were stored in tubes and kept at $4-5^{\circ} \mathrm{C}$ in dark. Before sampling, the honey tubes were gently heated to $50-60^{\circ} \mathrm{C}$. The declared botanical origin by the producers was considered. 


\section{Instrumentation}

Elemental analysis was carried out by XSeries II Inductively Coupled Plasma-Mass Spectrometry (ICP-MS; Thermo Scientific, Bremen, Germany). A MarsXpress microwave destructor system (CEM, Matthews NC, USA) of Teflon reaction vessels was used in all the digestion procedures. The reaction vessels were cleaned using $10 \mathrm{ml}$ of concentrated nitric acid before each digestion.

\section{Reagents and solutions}

All used chemicals were of analytical-reagent grade. Double-distilled water was used in all dilutions. $\mathrm{HNO}_{3}$ (Reanal, Budapest, Hungary) and $\mathrm{H}_{2} \mathrm{O}_{2}$ (Merck, Darmstadt, Germany) were of suprapure quality. The element standard solutions used for calibration were prepared by adequate dilution of standard solutions (1000 $\mathrm{mg} \mathrm{L}^{-1}$ ) of each element obtained by Sigma (Sigma -Aldrich, St. Louis MO, USA). The same procedure was applied to prepare the solutions of $\mathrm{Ga}, \mathrm{Pt}$ and $\mathrm{Rh}$ (1000mg L ${ }^{-1}$ stock solution, Sigma), which were chosen as the internal standards for the mass spectrometric technique.

\section{Determination of the elements}

Concentrations of macro- and trace elements were determined by ICP -MS. $250 \mathrm{mg}$ of each honey sample was homogenized and placed for $20 \mathrm{~h}$ in test tubes, which contained $6 \mathrm{ml}$ concentrated nitric acid $\left(\mathrm{HNO}_{3}\right)$ and $2 \mathrm{ml}$ $\mathrm{H}_{2} \mathrm{O}_{2}$. The samples were digested in a microwave destructor at $200^{\circ} \mathrm{C}$ for $25 \mathrm{~min}(1600 \mathrm{~W})$. Samples were then cooled and diluted with $12 \mathrm{ml}$ doubledistilled water. ICP-MS was used to determine the metal content in the honey samples. The operating parameters are presented in Table 1. Results were expressed in $\mu \mathrm{g}$ or ng element $\mathrm{g}^{-1}$ honey. Data are presented as average values $\pm \mathrm{SD}, n=3$.

Instrumental characteristics and setting for ICP-MS

\begin{tabular}{|l|l|}
\hline Spectrometer & Thermo Scientific XSeries II ICP-MS \\
\hline Nebulizer & Micromist \\
\hline Interface & Sampler and skimmer cones in Ni \\
\hline RF generator & $1400 \mathrm{~W}$ \\
\hline Argon flows (L/min) & 0.8 \\
\hline Nebulizer pump (rps) & 0.1 \\
\hline Scanning condition & number of replicate 3, dwell time $0.1 \mathrm{~s}$ \\
\hline Internal standards & ${ }_{31} \mathrm{Ga},{ }_{45} \mathrm{Rh},{ }_{78} \mathrm{Pt}$ \\
\hline
\end{tabular}




\section{Statistical analysis}

Different metal contents between distinct unifloral honey groups were subjected to one-way analysis of variance (ANOVA) to determine the presence of significant differences (Duncan test, significance level: $P<0.05$ ), using Sigma plot 11.0 software (Systat Software Inc., Erkrath, Germany). To compare the mineral content of the different honey types, Principal Component Analysis (PCA) ordination was performed using the matrix of variance-covariance of the $\log$-transformed $(\log 10(\mathrm{x}+1))$ data of honey samples (15 elements $\times 27$ honey samples). PCA is a multivariate method which is an objective way of addressing the problems of large numbers of variables and which is commonly used for clustering datasets (JolLIFFE 2002). A biplot ordination diagram, which gives a simultaneous display of both honey samples and elements, was used to visualize the results. PCA analysis was conducted with PAST 3.05 (HAMMER et al. 2001).

\section{RESULTS AND DISCUSSION}

\section{Differences in mineral content}

The mineral content of the studied unifloral honeys is shown in Table 2. $\mathrm{K}$ was the most abundant mineral in all unifloral honey samples. The $\mathrm{K}$ concentration ranged from 446.30 to $790.17 \mathrm{mg} \mathrm{kg}^{-1}$ in sunflower honey, while the average was $590.9 \mathrm{mg} \mathrm{kg}^{-1}$, which was significantly higher compared to the oilseed rape $\left(320.06 \mathrm{mg} \mathrm{kg}^{-1}\right)$ or black locust $\left(282.68 \mathrm{mg} \mathrm{kg}^{-1}\right.$ ) honeys (Table 2). Similar values of $\mathrm{K}$ were found in black locust honeys from Slovenia (Golob et al. 2005, Kropf et al. 2010) and Croatia (BILANDžIć et al. 2014), in sunflower honeys from India (КАмBOJ et al. 2013) and in oilseed rape honeys from Poland (Madejczyk, Baralkiewicz 2008, Chudzinska, Baralkiewicz 2010). However, ALQARNI et al. (2014) found more K in the black locust honey from Saudi Arabia compared to our results. The average Mg content was significantly higher in sunflower honey (30.49 $\mathrm{mg} \mathrm{kg}^{-1}$ ) compared to oilseed rape $\left(17.43 \mathrm{mg} \mathrm{kg}^{-1}\right.$ ) or black locust $\left(7.55 \mathrm{mg} \mathrm{kg}^{-1}\right.$ ) honeys (Table 2). The $\mathrm{Mg}$ concentration ranged from $24.23-38.71 \mathrm{mg} \mathrm{kg}^{-1}$ in sunflower honey. In comparison to our results, MADEJCZYK and BARALKIEWICZ (2008) found lower Mg content in oilseed rape honeys from Poland, while ALQARNI et al. (2014) found higher $\mathrm{Mg}$ content in black locust honeys from Saudi Arabia. However, BiLANDžić et al. (2014) and Devillers et al. (2002) found similar Mg content in black locust honey from Croatia and France.

Both the Mn and B contents showed significant differences in the honey types (Table 2). The Mn concentration was significantly lower in the black locust honey (0.13 $\left.\mathrm{mg} \mathrm{kg}^{-1}\right)$ compared to the sunflower $\left(0.19 \mathrm{mg} \mathrm{kg}^{-1}\right)$ and oilseed rape honeys $\left(0.23 \mathrm{mg} \mathrm{kg}^{-1}\right)$. The $\mathrm{Mn}$ content in the oilseed rape honeys from Poland and the black locust honeys from France was similar to that in 
Table 2

Average element contents of unifloral honey samples from the Hungarian Great Plain

\begin{tabular}{|c|c|c|c|}
\hline \multirow{2}{*}{ Parameter } & \multicolumn{3}{|c|}{ Honey type } \\
\hline & black locust $(n=9)$ & oilseed rape $(n=9)$ & sunflower $(n=9)$ \\
\hline $\begin{array}{c}\mathbf{K}\left(\mathrm{mg} \mathrm{kg}^{-1}\right) \\
\text { mean } \pm \\
\text { SD range } \\
\end{array}$ & $\begin{array}{l}282.68^{C} \pm 8.88 \\
195.73-400.70\end{array}$ & $\begin{array}{l}320.06^{B}+9.98 \\
197.20-473.70\end{array}$ & $\begin{array}{l}590.9^{A} \pm 14.23 \\
446.30-790.17\end{array}$ \\
\hline $\begin{array}{c}\mathbf{M g}\left(\mathrm{mg} \mathrm{kg}^{-1}\right) \\
\text { mean } \pm \mathrm{SD} \\
\text { range }\end{array}$ & $\begin{array}{c}7.55^{B} \pm 1.21 \\
4.94-14.77\end{array}$ & $\begin{array}{c}17.43^{B} \pm 1.81 \\
5.24-25.65\end{array}$ & $\begin{array}{c}30.49^{A} \pm 3.57 \\
24.23-38.71\end{array}$ \\
\hline $\begin{array}{c}\mathbf{F e}\left(\mathrm{mg} \mathrm{kg}^{-1}\right) \\
\text { mean } \pm \mathrm{SD} \\
\text { range }\end{array}$ & $\begin{array}{c}6.50^{\mathrm{NS}} \pm 1.00 \\
2.79-9.67 \\
\end{array}$ & $\begin{array}{c}6.18^{\mathrm{NS}} \pm 0.95 \\
2.90-9.26 \\
\end{array}$ & $\begin{array}{c}6.07^{\mathrm{NS}} \pm 1.16 \\
2.71-8.70\end{array}$ \\
\hline $\begin{array}{c}\mathrm{Zn}\left(\mathrm{mg} \mathrm{kg}^{-1}\right) \\
\text { mean } \pm \mathrm{SD} \\
\text { range }\end{array}$ & $\begin{array}{c}1.80^{\mathrm{NS}} \pm 0.56 \\
0.56-4.57\end{array}$ & $\begin{array}{c}1.73^{\mathrm{NS}} \pm 0.21 \\
0.34-3.05 \\
\end{array}$ & $\begin{array}{c}2.84^{\mathrm{NS}} \pm 0.71 \\
1.02-5.00\end{array}$ \\
\hline $\begin{array}{c}\mathbf{C u}\left(\mathrm{mg} \mathrm{kg}^{-1}\right) \\
\text { mean } \pm \mathrm{SD} \\
\text { range }\end{array}$ & $\begin{array}{c}1.91^{\mathrm{NS}} \pm 0.10 \\
0.36-4.47\end{array}$ & $\begin{array}{c}2.02^{\mathrm{NS}} \pm 0.07 \\
0.52-3.09 \\
\end{array}$ & $\begin{array}{c}1.94^{\mathrm{NS}} \pm 0.38 \\
0.57-3.71\end{array}$ \\
\hline $\begin{array}{c}\text { Mn }\left(\mathrm{mg} \mathrm{kg}^{-1}\right) \\
\text { mean } \pm \mathrm{SD} \\
\text { range }\end{array}$ & $\begin{array}{c}0.13^{B} \pm 0.02 \\
0.04-0.25 \\
\end{array}$ & $\begin{array}{c}0.23^{A} \pm 0.02 \\
0.12-0.34 \\
\end{array}$ & $\begin{array}{c}0.19^{A} \pm 0.01 \\
0.14-0.25 \\
\end{array}$ \\
\hline $\begin{array}{c}\mathbf{B}\left(\mathrm{mg} \mathrm{kg}^{-1}\right) \\
\text { mean } \pm \mathrm{SD} \\
\text { range }\end{array}$ & $\begin{array}{c}5.81^{B} \pm 0.31 \\
3.00-8.06 \\
\end{array}$ & $\begin{array}{c}15.98^{A} \pm 0.56 \\
5.19-35.24\end{array}$ & $\begin{array}{l}9.47^{B} \pm 0.29 \\
8.54-10.89\end{array}$ \\
\hline $\begin{array}{c}\mathrm{Al}\left(\mathrm{mg} \mathrm{kg}^{-1}\right) \\
\text { mean } \pm \mathrm{SD} \\
\text { range }\end{array}$ & $\begin{array}{c}1.58^{\mathrm{NS}} \pm 0.37 \\
0.83-2.34 \\
\end{array}$ & $\begin{array}{c}3.27^{\mathrm{NS}} \pm 0.30 \\
1.28-11.54 \\
\end{array}$ & $\begin{array}{c}2.13^{\mathrm{NS}} \pm 0.46 \\
1.30-3.23 \\
\end{array}$ \\
\hline $\begin{array}{c}\mathrm{Co}\left(\mathrm{mg} \mathrm{kg}^{-1}\right) \\
\text { mean } \pm \mathrm{SD} \\
\text { range }\end{array}$ & $\begin{array}{c}0.006^{\mathrm{NS}} \pm 0.001 \\
0.002-0.013\end{array}$ & $\begin{array}{c}0.008^{\mathrm{NS}} \pm 0.001 \\
0.003-0.016\end{array}$ & $\begin{array}{c}0.005^{\mathrm{NS}} \pm 0.001 \\
0.003-0.008\end{array}$ \\
\hline $\begin{array}{c}\mathrm{Ni}\left(\mathrm{mg} \mathrm{kg}^{-1}\right) \\
\text { mean } \pm \mathrm{SD} \\
\text { range }\end{array}$ & $\begin{array}{c}0.103^{\mathrm{NS}} \pm 0.025 \\
0.028-0.207 \\
\end{array}$ & $\begin{array}{c}0.085^{\mathrm{NS}} \pm 0.008 \\
0.058-0.105\end{array}$ & $\begin{array}{c}0.121^{\mathrm{NS}} \pm 0.017 \\
0.97-0.160\end{array}$ \\
\hline $\begin{array}{c}\text { Se }\left(\mathrm{mg} \mathrm{kg}^{-1}\right) \\
\text { mean } \pm \mathrm{SD} \\
\text { range }\end{array}$ & $\begin{array}{c}0.031^{\mathrm{NS}} \pm 0.009 \\
0.008-0.058 \\
\end{array}$ & $\begin{array}{c}0.019^{\mathrm{NS}} \pm 0.004 \\
0.001-0.070 \\
\end{array}$ & $\begin{array}{c}0.045^{\mathrm{NS}} \pm 0.007 \\
0.008-0.109\end{array}$ \\
\hline $\begin{array}{c}\text { Mo }\left(\mathrm{mg} \mathrm{kg}^{-1}\right) \\
\text { mean } \pm \mathrm{SD} \\
\text { range }\end{array}$ & $\begin{array}{c}0.007^{\mathrm{NS}} \pm 0.001 \\
0.003-0.011\end{array}$ & $\begin{array}{c}0.006^{\mathrm{NS}} \pm 0.001 \\
0.003-0.009\end{array}$ & $\begin{array}{c}0.010^{\mathrm{NS}} \pm 0.001 \\
0.004-0.022\end{array}$ \\
\hline $\begin{array}{c}\mathrm{As}\left(\mathrm{mg} \mathrm{kg}^{-1}\right) \\
\text { mean } \pm \mathrm{SD} \\
\text { range }\end{array}$ & $\begin{array}{c}0.067^{\mathrm{NS}} \pm 0.009 \\
0-0.188\end{array}$ & $\begin{array}{c}0.062^{\mathrm{NS}} \pm 0.006 \\
0.006-0.215\end{array}$ & $\begin{array}{c}0.034^{\mathrm{NS}} \pm 0.009 \\
0.009-0.082 \\
\end{array}$ \\
\hline $\begin{array}{c}\mathbf{P b}\left(\mathrm{mg} \mathrm{kg}^{-1}\right) \\
\text { mean } \pm \mathrm{SD} \\
\text { range }\end{array}$ & $\begin{array}{c}0.050^{\mathrm{NS}} \pm 0.009 \\
0-0.161\end{array}$ & $\begin{array}{c}0.022^{\mathrm{NS}} \pm 0.003 \\
0-0.063\end{array}$ & $\begin{array}{c}0.049^{\mathrm{NS}} \pm 0.013 \\
0.004-0.128\end{array}$ \\
\hline $\begin{array}{c}\text { Cd }\left(\mathrm{mg} \mathrm{kg}^{-1}\right) \\
\text { mean } \pm \mathrm{SD} \\
\text { range }\end{array}$ & $\begin{array}{c}0.001^{\mathrm{NS}}+0.001 \\
0-0.006\end{array}$ & $\begin{array}{c}0.005^{\mathrm{NS}} \pm 0.001 \\
0-0.012 \\
\end{array}$ & $\begin{array}{c}0.005^{\mathrm{NS}} \pm 0.001 \\
0.001-0.011 \\
\end{array}$ \\
\hline $\begin{array}{l}\text { The number of } \mathrm{s} \\
\text { SD = Standard } \\
\text { Means denoted } \\
\text { Duncan's multip } \\
\text { NS = not signific }\end{array}$ & $\begin{array}{l}\text { of each honey type } \\
\text { the mean. } \\
\text { rent letters indicat } \\
\text { e test). }\end{array}$ & icant differences a & .05 level (ANOVA, \\
\hline
\end{tabular}


the Hungarian samples (Madejczyk, Baralkiewicz 2008, Devillers et al. 2002). However, the black locust honeys from Saudi Arabia (AlqARNI et al. 2014) and Slovenia (Golob et al. 2005, Kropf et al. 2010) contained more Mn than those from Hungary. This is also true for the oilseed rape honeys from Switzerland (Bogdanov et al 2007). We found that the B (15.98 $\left.\mathrm{mg} \mathrm{kg}^{-1}\right)$ content of the rape honey was higher than that of the sunflower $\left(9.47 \mathrm{mg} \mathrm{kg}^{-1}\right)$ and black locust (5.81 $\mathrm{mg} \mathrm{kg}^{-1}$ ) honey (Table 2). The average B concentration was higher in the Hungarian oilseed rape honeys than in the Polish ones (MadejczyK, Baralkiewicz 2008, Chudzinska, Baralkiewicz 2010). In contrast, we did not find significant differences between the unifloral honey types considering their Fe (2.71-9.67 $\left.\mathrm{mg} \mathrm{kg}^{-1}\right), \mathrm{Zn}\left(0.34-5.00 \mathrm{mg} \mathrm{kg}^{-1}\right), \mathrm{Cu}(0.36-4.47 \mathrm{mg}$ $\left.\mathrm{kg}^{-1}\right)$, Al (0.83-11.54 mg kg-1), Co (0.002-0.016 $\left.\mathrm{mg} \mathrm{kg}^{-1}\right)$, Ni (0.028-0.207 mg $\left.\mathrm{kg}^{-1}\right)$, Se (0.001-0.109 $\mathrm{mg} \mathrm{kg}^{-1}$ ) and Mo (0.003-0.022 $\left.\mathrm{mg} \mathrm{kg}^{-1}\right)$ contents (Table 2). However, a higher Fe content was observed in the black locust honey from Saudi Arabia (ALqARNi et al. 2014) and a lower content occurred in such honeys in Slovenia (Golob et al. 2005), Croatia (BILANDžIĆ et al. 2014) and France (DevilLers et al. 2002). The trace element content of the investigated oilseed rape and sunflower honeys was similar to the trace element content of honey from Poland (MadejczyK, Baralkiewicz 2008, Chudzinska, Baralkiewicz 2010), India (Kamboj et al. 2013) and Switzerland (Bogdanov et al. 2007). The Zn content was higher in the sunflower honey from India (KAмBOJ et al. 2013) and the oilseed rape honey from Switzerland than in Hungarian samples (BoGDANov et al. 2007), but it was similar to the oilseed rape honey from Poland (Madejczyk, Baralkiewicz 2008, Chudzinska, Baralkiewicz 2010) and the black locust honey from Saudi Arabia (AlqARni et al. 2014), Switzerland (Bogdanov et al. 2007), Slovenia (Golob et al. 2005) and Croatia (BilanDžić et al. 2014). A study by MADEJCZYK and BARALKIEWICZ (2008) revealed similar content of $\mathrm{Cu}, \mathrm{Al}$ and $\mathrm{Ni}$ in the Polish oilsed rape honey compared to our results. Lower $\mathrm{Co}$ and higher Ni content was detected in the black locust honey from France (Devillers et al. 2002) and Saudi Arabia, compared to the Hungarian results (AlqARNI et al. 2014). BOGDANOv et al. (2007) measured similar $\mathrm{Ni}$ but lower $\mathrm{Cu}$ contents in the black locust and oilsed rape honey originating from Switzerland. However, the Croatian black locust honey contained higher $\mathrm{Cu}$ content (BILANDžIĆ et al. 2014). Moreover, Devillers et al. (2002) found a lower Al content in the black locust honey from France compared to the Hungarian samples.

We did not find any differences between the honey types considering their toxic element content $(\mathrm{As}, \mathrm{Pb}$ and $\mathrm{Cd})$ - Table 2. The average $\mathrm{As}$ $\left(0.067 \mathrm{mg} \mathrm{kg}^{-1}\right)$ and $\mathrm{Pb}\left(0.050 \mathrm{mg} \mathrm{kg}^{-1}\right)$ contents were the highest in the black locust honey and the average $\mathrm{Cd}$ content peaked in the oilseed rape honey $\left(0.005 \mathrm{mg} \mathrm{kg}^{-1}\right)$. On the other hand, we have to mention that the levels of toxic elements were under the detection limit in many honey samples. Chudzinska and Baralkiewicz (2010) found similar levels of $\mathrm{Pb}$ and $\mathrm{Cd}$ in the Polish oilseed rape honey and BogDANov et al. (2007) measured similar levels of $\mathrm{Pb}$ and $\mathrm{Cd}$ in Swiss black locust and oilseed rape honey. In the black 
locust honey from Saudi Arabia (Alqarni et al. 2014) and Slovenia (Golob et al. 2005), the levels of these elements were higher than in the Hungarian samples. However, BILANDžić et al. (2012, 2014) found similar As and Cd contents but higher $\mathrm{Pb}$ content in the black locust and oilseed rape honey from Croatia.

\section{Multivariate analysis of samples}

The ordination diagram of PCA also revealed differences among the unifloral honey types (Figure 2) and confirmed the results obtained with the

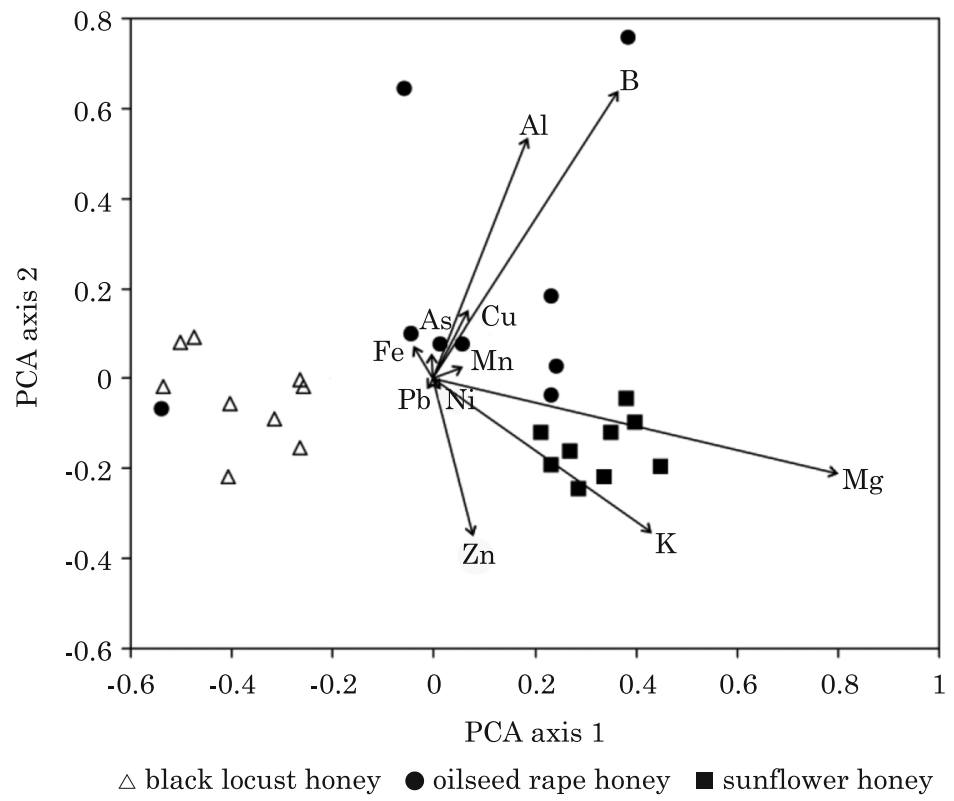

Fig. 2. Biplot ordination diagram of the first two Principal Component Analysis (PCA) axes with honey samples and elements (Al-Zn). Four elements (Co, Cd, Mo and Se) have minor influence on the separation of samples, and therefore are not shown in the figure. Percentage of variance explained by the PCA axis 1 and PCA axis 2 is $45 \%$ and $21 \%$, respectively

ANOVA. The PCA axis 1 explained 45\%, while the PCA axis 2 explained $21 \%$ of the variance in the mineral content. Axis 1 opposed black locust honey samples, on the left, and sunflower honey samples, on the right. Four out of nine oilseed rape honey samples were situated between the black locust and sunflower samples. One oilseed rape honey sample was very similar to black locust honey samples. There was considerable variation among the oilseed rape honey samples, whereas the sunflower honey samples were the most similar to one another. At the lower end of PCA axis 1, samples shoved a relatively low content of $\mathrm{Mg}, \mathrm{K}, \mathrm{B}$ and $\mathrm{Al}$, while at the higher end of this axis samples showed a relatively high content of $\mathrm{Mg}, \mathrm{K}, \mathrm{B}$ and $\mathrm{Al}$. Only two oilseed rape honey samples were separated clearly from the other samples 
along PCA axis 2 , by containing a relatively high content of $\mathrm{B}$ and $\mathrm{Al}$, and a relatively low content of $\mathrm{K}$ and $\mathrm{Zn}$. Other elements played a smaller role in the differentiation of samples. Four elements (Co, Cd, Mo and Se) which had the lowest influence on the separation of samples are not shown in Figure 2, although their eigenvector scores can be found in Table 3 .

Table 3

Eigenvector scores of elements in two main Principal

Component Analysis (PCA) axes

\begin{tabular}{|l|c|c|}
\hline \multicolumn{1}{|c|}{ Elements } & $\begin{array}{c}\text { PCA axis } 1 \\
(45 \%)\end{array}$ & $\begin{array}{c}\text { PCA axis } 2 \\
(21 \%)\end{array}$ \\
\hline $\mathrm{Mg}$ & 0.7981 & -0.2093 \\
\hline $\mathrm{K}$ & 0.4275 & -0.3398 \\
\hline $\mathrm{B}$ & 0.3636 & 0.6389 \\
\hline $\mathrm{Al}$ & 0.1837 & 0.5322 \\
\hline $\mathrm{Zn}$ & 0.0755 & -0.3454 \\
\hline $\mathrm{Cu}$ & 0.0670 & 0.1477 \\
\hline $\mathrm{Mn}$ & 0.0514 & 0.0230 \\
\hline $\mathrm{Fe}$ & -0.0382 & 0.0686 \\
\hline $\mathrm{Pb}$ & -0.0073 & -0.0130 \\
\hline $\mathrm{Ni}$ & 0.0066 & -0.0164 \\
\hline $\mathrm{Se}$ & 0.0052 & 0.0017 \\
\hline $\mathrm{As}$ & -0.0031 & 0.0499 \\
\hline $\mathrm{Mo}$ & 0.0019 & -0.0018 \\
\hline $\mathrm{Cd}$ & 0.0011 & -0.0007 \\
\hline $\mathrm{Co}$ & 0.0010 & 0.0018 \\
\hline $\begin{array}{l}\text { Matrix of } 15 \text { elements } \times 27 \text { unifloral honey samples. Values } \\
\text { are ranked in order of absolute magnitude along PCA axis } 1 . \\
\text { Values in parentheses indicate variance accounted for by } \\
\text { each axis. }\end{array}$ & & \\
\hline
\end{tabular}

\section{CONCLUSIONS}

The results obtained from the trace element analysis showed that differences in major, trace and toxic elements between Hungarian unifloral honey as well as a detailed comparison of honey samples with different geographic origins can be used for quality assessment. We can conclude that the investigated honey types were of good quality and contained only very small amounts of toxic elements ( $\mathrm{As}, \mathrm{Pb}$ and $\mathrm{Cd}$ ). However, their $\mathrm{K}, \mathrm{Mg}, \mathrm{B}$ and $\mathrm{Fe}$ contents were relatively high and the total mineral content decreased in order of sunflower, oilseed rape and black locust. According to the multivariate method, the $\mathrm{Mg}, \mathrm{B}, \mathrm{Al}, \mathrm{K}$ and $\mathrm{Zn}$ contents of the samples are considered to be the most important indicator for differentiating between the investigated honey samples and types. 


\section{ACKNOWLEDGEMENTS}

We would like to thank the beekeepers of the Hungarian Great Plain for providing the honey samples. We thank Erzsébet Porkoláb for her excellent technical assistance.

\section{REFERENCES}

Alqarni A. S., Owayss A. A., Mahmoud A. A., Hannan M. A. 2014. Mineral content and physical properties of local and imported honeys in Saudi Arabia. J. Saudi Chem. Soc., 18(5): 618-625.

Bilandžić N., GaČić M., Đokić M., Sedak M., Šipušić Đ. I., Končurat A., Gajger I. T. 2014. Major and trace elements levels in multifloral and unifloral honeys in Croatia. J. Food Compos Anal., 33(2): 132-138.

Bogdanov S., Haldimann M., Luginbühl W., Gallmann P. 2007. Minerals in honey: environmental, geographical and botanical aspects. J. Apicult. Res., 46(4): 269-275.

Chen H., Fan C., Chang Q., Pang G., Hu X., Lu M., Wang W. 2014. Chemometric determination of the botanical origin for Chinese honeys on the basis of mineral elements determined by ICP-MS. J. Agr. Food Chem., 62(11): 2443-2448.

Chudzinska M., Baralkiewicz D. 2010. Estimation of honey authenticity by multielements characteristics using inductively coupled plasma-mass spectrometry (ICP-MS) combined with chemometrics. Food Chem. Toxicol., 48(1): 284-290.

Citak D., Silici S., Tuzen M., Soylak M. 2012. Determination of toxic and essential elements in sunflower honey from Thrace Region, Turkey. Int. J. Food Sci. Tech., 47(1): 107-113.

Conti M.E., Botrè F. 2001. Honeybees and their products as potential bioindicators of heavy metals contamination. Environ. Monit. Assess., 69(3): 267-282.

Czipa N., Borbely M., Kovacs B. 2008. The effect of geographical origin on the composition of honey. Cereal Res. Commun., 36: 1435-1438.

de Alda-Garcilope C., Gallego-Picó A., Bravo-Yagüe J.C., Garcinuño-Martínez R.M., Fernández-Hernando P. 2012. Characterization of Spanish honeys with protected designation of origin "Miel de Granada" according to their mineral content. Food Chem., 135(3): 1785-1788.

Devillers J., Doré J.C., Viel C., Marenco M., Poirier-Duchêne F., Galand N., Subirana M. 2002. Typology of French acacia honeys based on their concentrations in metallic and nonmetallic elements. In: Honey Bees: Estimating the Environmental Impact of Chemicals. Ed. by Devillers J. and Minh-HA P.D. London, pp 248-268.

Golob T., Doberšek U., Kump P., NečEmer M. 2005. Determination of trace and minor elements in Slovenian honey by total reflection X-ray fluorescence spectroscopy. Food Chem., 91(4): 593-600.

Hammer Ř., Harper D.A.T., Ryan P.D. 2001. PAST: Paleontological statistics software package for education and data analysis. Palaeontol. Electron., 4(1): 1-9.

Hernández O.M., Fraga J.M.G., Jimenez A.I., Jimenez F., Arias J.J. 2005. Characterization of honey from the Canary Islands: Determination of the mineral content by atomic absorption spectrophotometry. Food Chem., 93(3): 449-458.

Jolliffe I. 2002. Principal Component Analysis. Springer, New York, $2^{\text {nd }}$ edition.

Kamboj R., Bera M., Nanda V. 2013. Chemometric classification of Northern India unifloral honey. Acta Aliment. Hung., 42(4): 540-551.

KašKonienè V., Venskutonis P.R. 2010. Floral markers in honey of various botanical and geographic origins: A review. Compr. Rev. Food Sci. F., 9(6): 620-634.

Kropf U., Korošec M., Bertoncelj J., Ogrinc N., Nečemer M., Kump P., Golob T. 2010. Determination of the geographical origin of Slovenian black locust, lime and chestnut honey. Food Chem., 121(3): 839-846. 
Madejczyk M., Baralkiewicz D. 2008. Characterization of Polish rape and honeydew honey according to their mineral contents using ICP-MS and F-AAS/AES. Anal. Chim. Acta, 617(1): 11-17.

Nowak L., Dzieżyc H., Piotrowski M. 2011. Content of bioelements and toxic metals in honey of various botanical orgin from Lower Silesia. J. Elem., 16(3).

Pisani A., Protano G., Riccobono F. 2008. Minor and trace elements in different honey types produced in Siena County (Italy). Food Chem., 107(4): 1553-1560.

PrzybyŁowski P., Wilczyńska A. 2001. Honey as an environmental marker. Food Chem., 74(3): 289-291.

PoHL P. 2009. Determination of metal content in honey by atomic absorption and emission spectrometries TrAC. Trend. Anal. Chem., 28(1): 117-128.

Stankovska E., Stafilov T., Šajn R. 2008. Monitoring of trace elements in honey from the Republic of Macedonia by atomic absorption spectrometry. Environ. Monit. Assess. 142(1-3): 117-126.

Szứcs J. 2010. Beekeeping in Csongrád. Acta Ethnog. Acad. Sci. Hung., 55(1): 157-170.

Terrab A., Hernanz D., Heredia F. J. 2004. Inductively coupled plasma optical emission spectrometric determination of minerals in thyme honeys and their contribution to geographical discrimination. J. Agr. Food Chem., 52(11): 3441-3445.

Tóтн P. 2011. Hungarian Apiological National Programme on Monitoring Environmental Pollution 2010-2011. OMME, Budapest, ISSN 2062-9915. (in Hungarian)

Tuzen M., Silici S., Mendil D., Soylak M. 2007. Trace element levels in honeys from different regions of Turkey. Food Chem., 103(2): 325-330.

Zajácz E., Szalai T., Mészáros G. 2008. Evaluation of the apicultural value of sunflower hybrids. Acta Agron. Hung., 56(1): 91-97. 